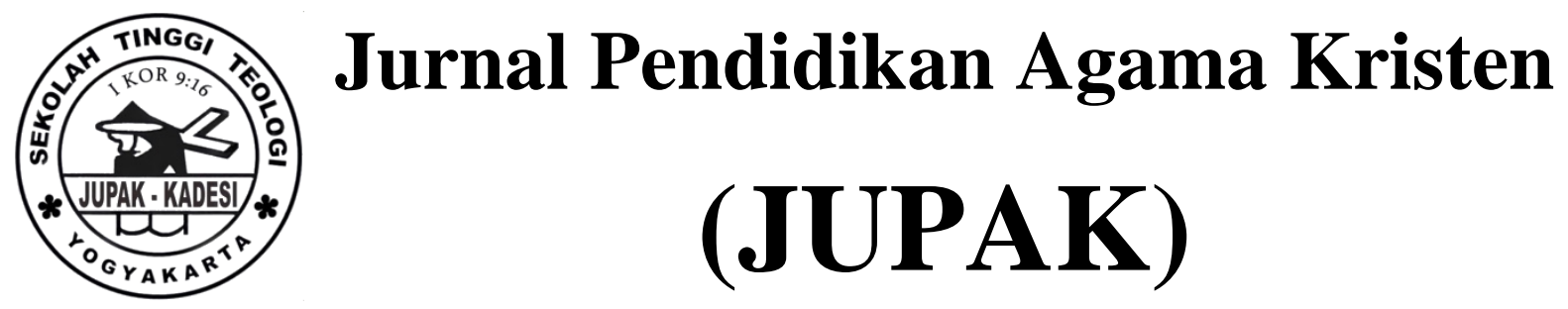

Vol. 1 No. 2 (June 2021) hlm. 124-143

Jurnal Pendidikan Agama Kristen (JUPAK)

e-ISSN 2774-3861

https://ejurnal.sttkadesiyogyakarta.ac.id/index.php/jupak

p-ISSN 2774-6399

https://doi.org/10.52489/jupak.v2i1.24

\title{
Peran Guru PAK Sebagai Teladan dalam Meningkatkan Kerohanian dan Karakter Peserta Didik
}

\author{
Reni Triposa $^{1)}$, Yonatan Alex Arifianto ${ }^{2)}$, Yudi Hendrilia ${ }^{3)}$ \\ Sekolah Tinggi Teologi Sangkakala, Salatiga.renitriposa@sttsangkakala.ac.id
}

\section{Recommended Citation}

Turabian $8^{\text {th }}$ edition (full note)

Reni Triposa, Yonatan Alex Arifianto, and Yudi Hendrilia, "Peran Guru PAK Sebagai Teladan Dalam Meningkatkan Kerohanian Dan Karakter Peserta Didik," Jurnal Pendidikan Agama Kristen (JUPAK) 1, no. 2 (June 16, 2021): 1, accessed August 6, 2021, https://ejurnal.sttkadesiyogyakarta.ac.id/index.php/jupak/article/view/24.

American Psychological Association $7^{\text {th }}$ edition

(Triposa et al., 2021, p. 1)

Received: 18 May 2021

Accepted: 25 Mey 2021

Published: 16 June 2021

This Article is brought to you for free and open access by Sekolah Tinggi Teologi Kadesi Yogyakarta. It has been accepted for inclusion in Christian Perspectives in Education by an authorized editor of Jurnal Pendidikan Agama Kristen (JUPAK).

For more information, please contact juniorichson1995@gmail.com 


\begin{abstract}
The state of the age and its development so rapidly influencing the world become a challenge for students and especially teachers in giving roles and tasks to education especially Christian education. But the role of the teacher in writing that uses library research with a qualitative descriptive approach is expected to improve human resources and bring students to grow in spirituality and character that can build a nation through a person who is strong in relying on God. The Role of Teachers Christian religious education as a role model in enhancing the spirituality and character of learners must be a priority in learning as a form of implying affective values. Teachers as role models in improving the spirituality and character of students, the teacher in this study was asked to have the first responsibility in carrying out the tasks, roles and responsibilities of teachers of Christian religious education. Then the teacher must realize that the Christian Religious Education teacher is an exemplary leader. And then the Master works closely with the church and family to bring about an increase in spirituality and character. And finally the Master must be led by the Holy Spirit.
\end{abstract}

Keywords: Christian religious education, Christian teacher, character, spirituality.

\begin{abstract}
Abstrak
Keadaan zaman dan perkembangannya yang sangat begitu cepat mempangaruhi dunia menjadi tantangan tersendiri bagi peserta didik dan yang terutama guru dalam memeberikan peran dan tugas pendidikan terlebih pendidikan Kristen. Namun peran guru dalam penulisan yang menggunakan penelitian pustaka dengan pendekatan kualitatif deskriptif diharapkan dapat meningkatkan Sumber daya manusia dan membawa anak didik bertumbuh dalam kerohanian dan karakter yang dapat membangun bangsa melalui pribadi yang tangguh mengandalkan Tuhan. Peran Guru PAK sebagai teladan dalam meningkatkan kerohanian dan karakter peserta didik haruslah menjadi prioritas dalam pembelajaran sebagai bentuk mengimplikasikan nilai secara afektif. Guru sebagai teladan dalam meningkatkan kerohanian dan karakter peserta didik maka guru dalam penelitian ini diminta yang pertama memiliki tanggung jawab dalam mengerjakan tugas, Peran dan tanggung jawab guru pendidikan Agama Kristen. Lalu guru harus menyadari bahwa guru Pendidikan Agama Kristen sebagai pemimpin keteladanan. Dan selanjutnya Guru bekerja sama dengan gereja dan keluarga membawa dalam peningkatan kerohanian dan karakter. Dan yang terakhir Guru harus dipimpin Roh Kudus.
\end{abstract}

Kata kunci: Pendidikan agama kristen, Guru Kristen, karakter, kerohanian.

\title{
PENDAHULUAN
}

Perubahan zaman yang cepat dengan kemajuan teknologi informatika dan digital membuat kehidupan sosial baik komunikasi dan kehidupan bermasyarakat juga mengalami perubahan hal itu merupkan prestasi namun juga dapat menimbulkan permasalahan dalam sosial masyarakat. Memang era zaman yang dengan kondisi kemajuan teknologi dan informatika dalam era globalisasi yang tidak dapat dielakan saat ini, di mana perkembangan iptek terus terjadi tanpa memperhatikan keadaan etika, moral dan karakter manusia (Telaumbanua, 2019), esensi negatifnya pemeran teknologi hanya mengejar untuk menekan 
segala lini kehidupan manusia supaya tidak lagi bergantung kepada Allah, namun bergantung dengan teknologi dan era komunikasi digital sebagai bagian kehidupan yang tidak dapat ditinggalkan. Sehingga manusia menjadi apatis ataupun kasih mereka menjadi dingin (Matius 24: 12). Padahal bangsa Indonesia sedang membangun dan melaksanakan tugas memperbaiki moral dan karakter bangsa dengan menjalani suatu gerakan nasional yaitu gerakan "pembangunan karakter" untuk mengatasi berbagai masalah dan persoalan yang menghambat kesejahteraan masyarakatnya (Intarti, 2016). Akan tetapi dengan perkembangan media dan tekhnologi menjadi tantangan dalam sebuah pendidikan karakter yang mencakup dalam nilai kerohanian dan karakter. Persoalannya yang terjadi saat ini dalam dunia revolusi industry 4.0. Banyak orang tua yang memberikan kebebasan dan keluasan dalam memfasilitasi anak dengan membelikan perangkat digital atau gadget sejak usia dini. Mereka memiliki tindakan alasan menjamin keamanan dan dapat pula menenangkan serta bagi orang tua ini cara yang mudah dalam pengawasan aktifitas anak mereka. Tapi meraka belum memikirkan bagaimana pengaruh, kecanduan game, media terhadap perkembangan yang muncul dari kebiasaan dan menjadi gaya hidup anak dalam memainkan gadget (Chusna, 2017). Gadget juga memiliki pengaruh besar terhadap kehidupan manusia, demikian pula terhadap anak-anak. Jika masa kanak-kanak sudah tercandu dan memiliki ketergantungan akibat dari dampak negatif oleh gadget dan perangkat sosial media, maka perkembangan anak pun akan terhambat ("Hubungan Peran Keluarga Dalam Menghindari Dampak Negatif Penggunaan Gadget Pada Anak Dengan Perilaku Anak Dalam Penggunaan Gadget Di Desa Kiawa 2 Barat Kecamatan Kawangkoan Utara,” 2018). Karena sejatinya kecanduan gadget dapat mempengaruhi perkembangan otak anak karena produksi hormon dopamine yang berlebihan menganggu kematangan fungsi prefrontal korteks yaitu mengontrol emosi, kontrol diri, tanggung jawab,yang dapat mempengaruhi pengambilan keputusan terlebih berdampak pada nilai-nilai moral lainnya. Dan hal lainnya yang diakibatkan karena kecanduan gadget dapat menimbulkan gangguan pemusat perhatian dan hiperaktivitas (Setianingsih et al., 2018).

Terlebih juga gadget alias smartphone memiliki dampak negatif bagi keterampilan sosial dan prestasi belajar (Dewanti et al., 2016), dan juga tidak dipungkiri gadget dapat juga berdampak positif bagi mereka yang tahu menggunakan dan tidak diperbudak olehnya namun jika dalam penggunaannya dilakukan secara terus menerus, salah satunya akan memiliki efek samping seperti penyakit gangguan kejiwaan (Maulida, 2013), dan dampak negative lainnya yang akan muncul diantaranya: akan sulit bersosialisasi, lamban dalam perkembangan motori, dan perubahan perilaku yang signifikan. Sehingga sangat penting peran guru 
disekolah terlebih orang tua untuk mengawasi, mengontrol dan memperhatikan segala aktivitas anak hyang menyangkut pergaulan, gadget dan tindakan dari pembentukan karakter anak (Chusna, 2017).

Bukan saja gadget namun persoalan yang terjadi di Indonesia adalah perundungan siber tidak hanya menimpa kalangan artis dan pejabat saja, tetapi juga masyarakat biasa. Beberapa kasus bahkan menyebabkan korbannya bunuh diri. akan tetapi, pelaku merasa hal itu wajar dan menganggap tidak bersalah (Rastati, 2016). Miris terdengar dengan kondisi hal ini, apalagi bangsa Indonesia terkenal dengan sopan santunya. Tetapi yang terjadi bertolak belakang dengan fakta yang ada. Aning Azzahra menyatakan bahwa: perundungan yang terjadi disebabkan karena perasaan ingin diakui, dihargai, diperlakukan adil, diperhatikan. Perundungan merupakan salah satu cara melampiaskan keinginan- keinginan para pelaku perundungan akibat adanya kegagalan peran guru dan keluarga dalam mengawasi dan memberikan perhatian (Azzahra \& Haq, 2019). Dan akibat gadget yang tanpa pengawasan orang tua, mengakibatkan adanya perundungan maya seperti yang diungkapkan Sartana dan Afriyeni bahwa: perundungan maya banyak menyebabkan korban mengalami perasaan marah, malu, tidak bisa konsentrasi belajar, dan takut. Korban perundungan maya mengaku bahwa memiliki dampak mental lebih serius dibanding dengan perundungan di dunia nyata (Dan \& Afriyeni, 2017). Dari contoh diatas ini persoalan serius dalam dunia pendidikan dan keluarga maka dengan latar belakang permasalahan, tersebut maka penulis meneliti dengan kajian pustaka bagaimana peran guru pendidikan agama Kristen sebagai teladan dalam meningkatkan kerohanian dan karakter peserta didik? Untuk membawa generasi takut akan Tuhan dan ada dalam pertumbuhan iman, kasih dan pengenalan akan Tuhan yang dapat membawa bangsa menjadi lebih baik. dan pendidikan agama Kristen yang merupakan pendidikan yang berpusat kepada Allah (Berkhof \& Til, 2012, p. 15).

\section{METODOLOGI PENELITIAN}

Jenis penelitian dalam paper ini adalah penelitian pustaka dengan pendekatan kualitatif deskriptif (Umrati \& Wijaya, 2020, p. 12). Penulis melakukan kajian terhadap sumber-sumber pustaka dan menguraikannya dalam sebuah kerangka uraian sebagai berikut. Analisis dimulai dari peran guru Pendidikan agama Kristen, selanjutnya menjabarkan guru sebagai teladan. Selain menggunakan Alkitab sebagai referensi sejarah, juga dipergunakan buku-buku dan sumber-sumber primer lain yang relevan dengan topik sesuai prinsip literatur review yang dimaksud oleh Denney (Denney \& Tewksbury, 2013). Penulis juga 
menggunakan sumber-sumber acuan yang dapat melengkapi artikel ini yang masih dianggap menjadi sumber utama. Penulis juga menggunakan sumber teks Alkitab dalam menggali peran guru dan kerohania dan karakter yang Alkitabiah. Selain itu, penulis menggunakan beberapa sumber tambahan dari buku-buku yang membahas dari peran guru Pendidikan agama Kristen sebagai teladan dalam meningkatkan kerohanian dan karakter peserta didik sebagai prinsip-prinsip membawa kebaikan dan dampak yang baik dengan mengacu dan merujuk dari berbagai sumber jurnal yang sudah terakreditasi.

\section{HASIL DAN PEMBAHASAN}

\section{Tugas, Peran dan Tanggungjawab Guru Pendidikan Agama Kristen}

Mengenai tugas, peran dan tanggung jawab guru selalu memiliki pro dan kontra, namun sejatinya dalam dunia pendidikan, guru adalah kunci pendidikan yang dapat membawa peserta didik mampu memberikan pemahaman dalam pengetahuan, kerohanian serta mampu menggapai prestasi maupun mampu menjadi pribadi yang memliki iman dan karakter yang baik. Iman harus nyata dalam kehidupan sehari- hari, misalnya dalam aspek sosial kemasyarakatan, keadilan, dan lain-lain (Budiyana, 2020, p. 72). Guru adalah figur inspirator dan motivator peserta didik bahkan menjadi panutan dalam mengapai masa depannya. Sebab ketika mampu menjadi sumber inspirasi dan motivasi bagi anak didiknya, maka hal itu akan membawa semangat perubahan untuk menjadi manusia yang menjadi berkat. Selaras dengan yang disampaikan Intarti bahwa: memang guru tidak hanya dituntut untuk memiliki pemahaman atau kemampuan dalam bidang belajar dan pembelajaran tetapi juga dalam memotivasi peserta didik (Intarti, 2016). Selaras dengan hal tersebut maka intarti mengungkapkan bahwa ada peran guru yang penting dalam dunia pendidikan yaitu: Guru memiliki tiga peran utama yaitu sebagai pengajar, pelatih, dan pendidik. Sebagai pengajar, guru berfungsi menyiapkan rencana pembelajaran, menyajikan program dan kurikulum sampai melakukan evaluasi ketuntasan program pengajaran. Lalu guru Sebagai pelatih, guru wajib memperlengkapi peserta dengan keterampilan-keterampilan yang akan mendukung kemampuan kognitif peserta didik untuk menunjang dan memperlengkapi masa depannya kelak dengan baik. Dan yang terakhir guru Sebagai pendidik, guru berkewajiban membekali peserta didik dengan Veleu dan sikap tingkah laku atau karakter yang sesuai dengan norma agama dan hukum negara (Intarti, 2016).

Begitu juga dengan peran pemerintah dalam Undang-undang Nomor 20 Tahun 2003 tentang Sistem Pendidikan Nasional menyebutkan bahwa Pendidikan adalah usaha sadar dan 
terencana untuk mewujudkan suasana belajar dan proses pembelajaran agar peserta didik secara aktif mengembangkan potensi dirinya untuk memiliki kekuatan spiritual keagamaan, pengendalian diri, kepribadian, kecerdasan, akhlak mulia, serta keterampilan yang diperlukan dirinya, masyarakat bangsa dan negara (pasal 1, butir 1). Pendidikan menjadi bagian terpenting dalam seluruh aspek kehidupan baik itu pendidikan secara formal, maupun pendidikan non formal (Baskoro, 2020, p. 48). Mengharapkan guru sebagai garda terdepan pendidikan dapat mengupayakan dalam pengembangan di dunia pengetahuan, spiritual keagamaan dan akhlak mulia supaya berguna bagi bangsa dan negara. Dan pemerintah juga menegaskan dalam Undang-undang Nomor 20 Tahun 2003 tentang Sistem Pendidikan Nasional. Dalam Pasal 3 UU tersebut dinyatakan bahwa "Pendidikan nasional berfungsi mengembangkan kemampuan dan membentuk watak serta peradaban bangsa yang bermartabat dalam rangka mencerdaskan kehidupan bangsa, bertujuan untuk berkembangnya potensi peserta didik agar menjadi manusia yang beriman dan bertakwa kepada Tuhan Yang Maha Esa, berakhlak mulia, sehat, berilmu, cakap, kreatif, mandiri, dan menjadi warga negara yang demokratis serta bertanggung jawab." Sejalan dengan hal tersebut pembentukan karakter siswa guru agama Kristen pada dasarnya tidak hanya menekankan pada kognitif dan psikomotorik tetapi lebih pada keterampilan karakter afektif yang membawa perubahan karakter dan juga seharusnya seperti yang dilakukan sebagai tugas pokok guru agama Kristen dituntut untuk mentransfer pengetahuan mereka dalam kehidupan sehari-hari (Simorangkir \& STAKN Tarutung, 2013).

Tanggung jawab guru juga membantu peserta didik agar dapat mengembangkan potensi yang dimilikinya secara maksimal. Potensi peserta didik yang harus dikembangkan bukan hanya mengenai persoalan kecerdasan dan keterampilan, melainkan menyangkut seluruh aspek kepribadian (Intarti, 2016). Hal itu didukung juga dalam peran guru merupakan satu-satunya agen perubahan yang memiliki tugas baik secara institusional maupun noninstitusional. Sebab peran guru pendidikan agama Kristen memiliki peranan, tugas dan tanggungjawab terhadap peserta didiknya. Sebab peran dan tanggung jawab guru tidak akan dapat digantikan dengan media pembelajaran atau dengan kemajuan teknologi dan imformatika sebab hubungan emosi antara guru dan murid adalah hal yang akan membewa perubahan. Sebagai pendidik yang memiliki tugas yang menyangkut pembinaan pemahaman pengetahuan dan sifat mental manusia yang menyangkut aspek-aspek yang bersifat kerohanian yang dapat mempengaruhi keselamatan orang lain jikalau guru apatis terhadap kerohanian anak peserta didiknya maka akan sulit bagi guru pendidikan agama Kristen dapat 
mengembalikan keadaan, namun yang ada akan datangnya penyesalan yang harus dipertanggungjawabkan sebagai pendidik. Oleh karena itu keberhasilan panggilan dalm pengajar atau pendidik tidak tergantung dari pemahan saja tentang hokum-hukum melainkan pada diri sebagai pribadi yang terbuka terhadap kuasa Tuhan yang mempersilahkan mengubah dan memperbaharui pikiran (Hendrick, 2011, p. 160).

Gurulah yang memang setiap hari berada didalam jam kelas pelajaran maupun dalam lingkungan sekolah dapat memberi pemahaman nilai rohani, norma, moral, etika, serta pembiasaan karakter positif (Utomo, 2017) yang dapat meningkatkan kognitif, apektif dan psikomotorik peserta didik dalam hal sains maupun kerohanian. Menyangkut Guru Pendidikan agama Kristen bahwa Pendidikan Agama, lebih khususnya pendidikan Agama Kristen sangatlah penting untuk diterapkan dalam peningkatan potensi spiritual, sehingga membantu dalam mengantarkan peserta didik agar menjadi pribadi yang beriman dan taat kepada Tuhan (Ermindyawati, 2019). Sebab Pendidikan Kristen adalah sebuah tugas ilahi yang dimandatkan oleh Yesus dalam Amanat Agung (Matius 28 : 19-20) tentang memberikan pengajaran kerohanian yang Alkitabiah. Tetapi pendidikan agama Kristen memiliki keunikannya melampui batas humanitas karena aspek subject matter, goal, dan spiritual dynamic yang tercakup di dalamnya. Sebab di Indonesia sejarah membuktikan bahwa melalui pendidikan Kristen tepatnya pendidikan agama Kristen Allah dengan kedaulatan-Nya beranugerah atas bangsa ini sehingga Injil dapat dikabarkan secara sistematis ke hampir seluruh nusantara (Widianing, 2018). Hal ini disebabkan karena pentingnya pengajaran pendidikan Agama yang dapat membawa kebaikan dan ajaran kasih Tuhan dalam menyentuh peserta didik lewat kehidupannya yang berkenan kepada Tuhan, hal ini sangatlah penting dalam kehidupan umat manusia, terlebih khususnya dalam agama Kristen (Ermindyawati, 2019).

Memang ada tantangan yang dihadapi dalam lingkup sosial dan pergaulan serta kecanduan gadget yang diluar dari pantauan guru maka lewat keteladan dan lewat hidup yang mengandalkan Tuhan guru diharuskan juga menjadi pendoa bagi peserta didiknya. Karena doa merupakan sebuah aktivitas kerohanian yang erat hubungannya dengan denyut nadi kekristenan; sehingga muncul semacam ungkapan, bahwa doa adalah nafas kehidupan orang percaya (Sutoyo, 2016). Sebab doa yang dipanjatkan pasti membawa Tuhan untuk campur tangan menolong apa yang menjadi pergumulan pendidik atau guru. Jika menelisik dalam history kehidupan tokoh Alkitab tidak lepas dari kebergantungnya kepada Tuhan. Yang pasti doa menjadi energi dari setiap pelayanan bahkan sendi kehidupan yang dilakukan (Sutoyo, 
2016) baik dalam kehidupan pengajaran dan pendidikan maupun dalam mengubah kerohanian anak dan karakter, karena Allah yang membawa perubahan lewat doa-doa yang dinaikan pendidik atau guru sebagai bagian mengandalkan Tuhan untuk kebaikan para peserta didik.

Peran guru dan pendidikan agama Kristen juga merupakan suatu proses dalam pembelajaran mengenai persekutuan, yang diharapkan dalam persekutuan ini yaitu kehidupan persekutuan komunitas iman yang di dalamnya memiliki nilai-nilai kehidupan personal atau pribadi dengan Tuhan dan sosial di mana satu sama lain atau terhadap sesama. Karena guru dan peserta didik ada dalam lingkup negara majemuk dan pluralism dalam konteks bangsa Indonesia guru dan pendidikan agama Kristen yang berperan dan bertanggungjawab diharapkan mampu memberikan pencerahan agar manusia menghormati kehidupan personal dan sosial dalam seluruh aspek kehidupan masyarakat Indonesia yang majemuk (Rantung, 2017), terlebih guru harus menyatakan kebenaran yang benar bukan dusta, kebohongan ataupun peaduga, sebab pengetahuan yang benar membawa orang percaya atau peserta didik percaya kepada Allah dan sumber kebenaran dan bukan meragukan apalagi meninggalkan dan menjauhi Tuhan (B.S Sidjabat, 2017, p. 128). Sebab Allah memberikan suatu misi kepada umat-Nya agar mengasihi dan bersaksi serta melayani seperti teladan-Nya kepada murid-murid-Nya. maka dari pada itu sangatlah diperlukan peran dari berbagai pihak termasuk dan teristimewa guru pendidikan agama Kristen dalam mengontrol dan memperhatiakn siswa sebagai tanggung jawab (Telaumbanua, 2019).

Karena itu, tugas dan tanggung jawab seorang guru baik guru pendidkan agama Kristen adalah tugas yang mulia dan profesi yang terhormat, seperti yang dilakukan Tuhan Yesus Kristus yang berkewajiban menjadi contoh utama para rasul dan murid dan untuk saat ini kepada orang Kristen atau para murid dari proses pendidikan dan Yesus menjadi kepala dalam proses pengajaran itu karena Yesus adalah Guru bagi semua guru, Ia tidak hanya menyampaikan informasi dan pengetahuan semata, namun juga Yesus memberi warna dan mengubah kehidupan orang-orang yang mengikuti-Nya (Simanjuntak, 2016). Dapat juga dipastikan bahwa moralitas hidup yang dalam pribadi orang Kristen adalah buah dari kehidupan yang dipersatukan dalan diri Yesus (Niyoko, 2017, p. 28), sebab diluar Yesus orang percaya tidak bisa berbuah. 


\section{Guru Pendidikan Agama Kristen sebagai pemimpin keteladanan}

Guru adalah teladan bagi murid, hal ini diharapkan oleh semua orang bahwa guru harus memberi dampak yang baik melalui Kepemimpinan. Karena kepemimpinan guru agama Kristen harus meiliki sumbangsih untuk meningkatkan kualitas proses pembelajaran dalam konteks sekolah dan pendidikan nasional, dan juga terlebih membawa peserta didik ada dalam koridor agama, namun ironisnya, guru agama Kristen masih kurang pengetahuan dalam kepemimpinan, dan tidak menerapkan kepemimpinan yang memadai dalam proses pembelajaran (Lumban Gaol \& Nababan, 2019). Hal ini terjadi karena Seorang guru pendidikan agama Kristen tidak terlalu berorientasi pada profesi, tetapi harus menjadi tanggung jawab bahwa tugas ini adalah panggilan Tuhan untuk melayani. Betapa pentingnya untuk menyadari bahwa panggilan untuk melayani adalah esensi dari profesi guru (Andriati, 1948). Sehingga yang terjadi dalam dunia pendidikan dan kerohanian salah satu persoalan disebabkan guru tidak sungguh-sungguh mengaplikatifkan ilmu dan teladan bagi peserta didik. Menurut Utomo persoalan terpenting dalam dunia pendidikan sesungguhnya adalah sebagai guru tidak sedang melakukan tugas pendidikan dalam arti sesungguhnya, namun hanya sekedar mengajar secara formalitas (Utomo, 2017). Namun sejatinya peran guru sangat penting dalam proses pendidikan. Seorang guru tidak hanya memberikan konten pelajaran kepada siswa, tetapi juga memberikan pendidikan karakter dengan menjadi contoh karakter dan integritas yang baik yang membawa anak didik untuk dapat mengikuti teladannya (Simanjuntak, 2016).seperti yang diampaikan oleh Andrianti bahwa: dilihat dari kenyataan yang terjadi bahwa pendidikan Kristen saat ini tidak hanya dituntut untuk memberikan dampak intelektual atau keterampilan kognitif, tetapi juga mampu memberikan implikasi pada moralitas bahkan ranah kerohanian peserta didik (Andrianti, 2012).

Namun jika didasari dari motivasi yang hanya sekadar dan menganggap itu bukan tugas guru akan berakibat fatal pendidikan dalam lingkup sekolah maupun lingkup kerohanian. Memang setiap orang baik guru maupun profesi yang lainnya mempunyai tujuan melakukan sebuah aktivitasnya. Terdorongnya seseorang melakukan sebuah kegiatan, akan berjalan bersama dengan motivasi yang kuat, Motivasi untuk mencapai maksudnya dengan memanfaatkan segala daya upaya yang dapat dilakukan (Saptono Yohanes Joko, 2016). Sehingga juga dapat meningkatkan motivasi belajar peserta didik begitu penting, sebab berpengaruh pada hasil belajar para murid. Sebab jika murid tidak memiliki motivasi dalam belajar, tidak mungkin dapat melakukan aktivitas belajar dengan baik. Dan yang terpenting adalah motivasi akan menentukan tinggi rendahnya pencapaian prestasi peserta didik 
(Saptono Yohanes Joko, 2016) dalam ranah pendidikan sekuler maupun pendidikan agama Kristen terlebih termotivasi untuk ada dalam kerohanian dan karakter yang baik.

Guru pendidikan agama Kristen sangat diharapkan agar dapat melaksanakan tugas dan kewajibanya dengan sebaik-baiknya dan sungguh-sungguh sesuai dengan tujuan pendidikan dan pembelajaran yakni membentuk dan menciptakan generasi yang berakhlak mulia, bertanggungjawab dan memiliki karakter Kristus (Telaumbanua, 2019). Selaras dengan tujuan Tuhan untuk menjadi terang dan garam bagi sesama (Matius 5:13-16). Karena dalam pembelajaran dan pengajaran pendidikan agama Kristen mempunyai peran penting dalam membantu pertumbuhan kerohanian siswa dalam lingkup pendidikan, pengajaran Pendidikan agama Kristen pada dasarnya sangat dibutuhkan dan memiliki pengaruh yang besar terhadap perilaku siswa-siswi (Ermindyawati, 2019), hal ini akan terjadi jika kepemipinan guru sebagai teladan dapat dipenuhi dan dilakukan dengan motivasi dan menyadari bahwa guru pendidikan agama Kristen adalah seorang hamba dan pelayan. Sebab pelayanan dalam pendidikan Kristen merupakan pelayanan yang sangat efektif untuk melayani Tuhan (Santoso, 2005). Supaya pendidikan agama Kristen yang merupakan sebuah proses pengajaran dan pembelajaran yang berdasarkan Alkitab dan berpusat pada Kristus. Pendidikan agama Kristen berperan untuk mengarahkan pribadi seseorang menuju pada pengenalan dan kedewasaan dalam Kristus (Nuh et al., 2019). Sehingga melalui pendidikan agama Kristen guru sebagai pemimpin dapat mengaplikasikan mandat Amanat Agung untuk memuridkan sebagai proses penginjilan yang bersifat berkelanjutan untuk mengajar mereka yang telah percaya kepada Tuhan Yesus, menjadi murid Kristus yang akan menghasilkan murid Kristus selanjutnya (Hutagalung, 2020). Dalam membentuk dan mengembangkan iman, kerohanian, dan karakter, serta pembentukan dan pengembangan pengetahuan (akademisi) dan kecakapan hidup (Binsen S. Sidjabat, 2020). Untuk menuju kea rah yang diinginkan baik maka guru perlu memperhatikan setiap perilaku siswa-siswinya dalam keseharian di lingkup sekolah dan memahami emosionalnya sebagai tindakan kepedulian terlebih selalu bijak dan bertindak dalam hal memberi pengajaran pendidikan agama Kristen yang dinyatakan dan dilakukan dengan mengasihi Allah. (Intarti, 2016)

\section{Guru Bekerja Sama dengan Gereja dan Keluarga Membawa Peningkatan Kerohanian dan Karakter}

Peran agama dalam kehidupan umat manusia sangat penting karena berkaitan dengan kehidupan spiritual yang membuat seseorang dengan keyakinannya mempercayai adanya 
Tuhan. Peran agama adalah untuk menjadi panduan dan penuntun dalam upaya menciptakan kehidupan yang bermakna, damai dan bermartabat. Tetapi dalam pendidikan agama Kristen maupun pendidikan dalam keluarga maupun dalam dunia pendidikan sekuler adalah upaya agar manusia dapat berkembang (Siburian, 2019). Begitu juga dalam karya pendidikan agama Kristen dalam keluarga bukan hanya mengajarkan pengetahuan agama Kristen, tetapi keluarga juga dapat menanamkan keteladanan dan praktek hidup toleran yang dasarnya cinta kasih Yesus Kristus yang sudah rela berkorban di salib untuk menebus dosa manusia. Dasar ini akan membawa pendidikan agama Kristen dalam keluarga untuk membentuk kerohanian yang mantang dan karakter Kristen pada diri anak-anak sejak dini dengan menjadi peribadi yang mentaati akan nilai-nilai Kristen dalam kehidupan sehari-hari (Hutabarat, 2019). Guru pendidikan agama Kristen juga dapat memiliki peran dalam mengajarkan nilai-nilai spritual dan memotivasi peserta didiknya. Sehingga dapat membawa semangat dalam belajar memperbesar kapasitas dalam dunia pendididikan dan kerohanian (Intarti, 2016). Dan gruru pendidikan agama Kristen adalah seseorang yang profesinya mengajar untuk mendewasakan peserta didik melalui pendidikan yang berisi ajaran kekristenan dengan menekankan ketiga aspek (kognitif, afektif dan psikomotorik) berdasarkan iman kristen. Juga harus bekerja sama dengan gereja dan keluarga untuk membangun kerohanian dan karakter.

Guru dalam kerja samanya dengan keluarga diharapkan untuk membangun tujuan dan memberi pengetahuan bahwa keluarga adalah tempat pendidikan yang pertama dan terutama. Dalam keluargalah anak mendapatkan pengajaran iman dan nilai-nilai moral. Seperti yang diterapkan dalam Perjanjian Lama, Pendidikan Agama Kristen dimulai dalam keluargakeluarga. Hal ini terjadi dalam keluarga Bapa-bapa leluhur yaitu Abraham, Ishak dan Yakub. Mereka sebagai orang tua mewariskan iman kepada keturunannya, bahkan kepada seluruh bangsa Israel (Hastuti, 2013). Tetapi yang perlu diperhatikan bila guru bekerja sama dengan gereja karena dikuatirkan ada kecenderungan bahwa gereja dan bagian orang percaya belum maksimal dalam menjalankan fungsi sosialnya (Saragih, 2019). Karena gereja juga bagian dari sosial yang berkaitan langsung dengan pendidikan. Namun diharapkan Gereja melalui Pendidikan Kristen memiliki tanggungjawab untuk membangun pemahaman jemaat menjadi dewasa dalam Kristus (Darmawan, 2014). Karena dalam gereja ada misi pendidikan agama Kristen ialah memberikan perubahan kehidupan sosial yang menyeluruh ditengahtengah masyarkat majemuk (Sagala, 2017). Terlebih dalam keluarga ada peran orangtua dalam mengajarkan pendidikan Kristen kepada anak dan kehidupan orang remaja yaitu untuk mengajarkan firman Tuhan, orang tua harus mau menjadi pendidik, menjalankan disiplin, 
menjadi teladan bagi anak maupun anak remaja (Wadi \& Selfina, 2016). Seperti yang dilakukan oleh para tokoh Alkitab PL dan PB. Bisa dipastikan pengajaran Yesus dalam Perjanjian Baru, Tuhan Yesus sebagai Guru Agung selalu mengajarkan tentang iman kepada para pendengar-Nya. maka begitu juga keluarga Kristen adalah sebagai tempat untuk mengajarkan iman kepada anak-anak (Hastuti, 2013). Keluarga adalah tempat pendidikan meprioritaskan anak mendapatkan pengajaran iman kepercayaan kepada Tuhan dan nilainilai moral (Hastuti, 2013), yang sejalan dengan pemikiran dan tujuan Alkitab. Karena sejarah gereja membuktikan, bahwa Alkitab selalu menjadi sumber utama atau alkitan adalah pusat pendidikannya (Eli Tanya, 2006, p. 19).

Hal ini akan maksimal jika Semua komponen bangsa dan masyarakat baik gereja, keluarga, guru dan murid atau anak diharapkan memberi kontribusinya. Sebab dalam pendidikan agama Kristen sebagai salah satu tugas gereja yang strategis dapat memberi kontribusinya yang penting bilamana dalam semua program yang berkaitan dengan pendidikan agama Kristen bagi semua kategori usia dan berbagai konteks (keluarga, gereja dan sekolah) dapat mengutamakan dimensi karakter (Nuhamara, 2018). Sebab sebagai guru agama yang bekerja sama dengan siapa saja dapat memaknai bahwa guru agama Kristen mempunyai peran yang sangat penting bagi anak didik dalam mempelajari, mengkaji, mendidik dan membina kehidupannya dalam kebenaran (Sahartian, 2018). Hal itu untuk menjadikan keluarga sebagai pusat bermisi dalam memberitakan firman Tuhan yang dengan cara menjadikan keluarga itu sebagai tempat pertama untuk menyebarkan Firman Allah, baik itu melalui pengajaran maupun teladan dalam kehidupan (Hastuti, 2013) Karena dalam pendidikan Kristen peran guru, gereja dan keluarga harus membawa setiap murid ataupun anak dalam keluarga membawanya untuk maju dengan mengarah pada pendidikan agama yang memiliki kesadaran akan dosa, pendidikan agama yang berpusat kepada Yesus Kristus, pendidikan agama yang memiliki perspektif dan tujuan dalam kekekalan, pendidikan dengan holistik subjek dan pendidikan yang memabwa orang datang pada Yesus dan pendidikan yang memuridkan (Nadeak \& Hidayat, 2017). Karen memang makna dan tugas pendidikan Kristen dalam memuridkan jiwa sesuai dengan Amanat Agung (Widianing, 2018) Sebab ini menjadi pola dan contoh dalam keluarga Kristen lainnya yang belum menjalankan prinsip seperti ini dan dengan pendidikan dalam keluarga yang akan menjadi dasar pondasi karakter dalam berprilaku dan bersikap dalam bermasyarakat (Chusna, 2017). Sebab Guru dalam perannya membawa pendidikan agama Kristen sebagai usaha pendidikan yang ingin menumbuhkembangkan kepribadian Kristen dalam diri peserta didiknya (GP, 2012, p. 61). 


\section{Guru dalam Pimpinan Roh Kudus}

Faktor Roh Kudus tidak boleh dilupakan dalam proses pembelajaran Kristen dan dalam hubungannya dengan pendidik ataupun guru. Roh Kudus adalah representasi Kristus yang berkarya secara supranatural sebagai Guru Agung dalam proses pembelajaran. Roh Kudus yang telah mewahyukan bahan ajar yang mutlak dan hakiki yaitu Alkitab yang kini turut bekerja dalam proses pembelajaran untuk memberi penerangan atau iluminasi sehingga guru bisa mengajar dengan baik dan murid atau anak didik bisa belajar dengan baik pula (Budiyana, 2018) Peran Roh Kudus juga dinyatakan dalam kasih karunia yang Dia berikan untuk meningkatkan kapasitas guru dan murid. Ada dimensi-dimensi yang harus dikembangkan secara akal budi. Tetapi, dalam hal dimensi spiritual, Roh Kudus harus merupakan satu-satunya Pribadi yang boleh mengisi dan memberi penguatan (Budiyana, 2018). Seperti yang diungkapkan oleh Arifianto dan sumiwi mengungkapkan: Roh Kudus menjadikan orang yang dituntunnya merdeka dari dosa dan intimidasi si jahat. lalu Roh Kudus memberikan hikmat dan pengertian untuk mengenal Yesus dan menghayatinya di setiap langkah perjalanan hidup. Dan yang terakhir Roh Kudus menuntun kepada seluruh kebenaran Allah, sehingga orang yang dituntunnya terhindar dari siasat penyesatan (Arifianto \& sumiwi Rachmani, 2020).

Sebab seharusnya peran pendidikan agama Kristen dalam menyampaikan kebenaran dan menjadi sarana untuk membimbing dan menuntun generasi muda yang sanggup menjadi saksi-saksi Kristus dalam kehidupan sehari-hari dan terlebih harus memegang teguh kebenaran dan membangun relasi yang baik dengan sesama (Eliasaputra et al., 2020). Pendidik Kristen telah mendapat tugas penting untuk mengajar orang dewasa di gereja, terutama bagaimana merancang dan mengembangkan kurikulum pendidikan Kristen secara kreatif. Kurikulum pendidikan Kristen memiliki fungsinya sebagai panduan untuk membantu pendidik Kristen untuk mengajar orang percaya baik anak-anak atau orang dewasa di gereja sehingga mereka mungkin dapat memahami citra diri atau konsep diri mereka, peran dan tugas mereka sebagai orang dewasa secara khusus dan signifikan dalam kehidupan seharihari mereka dan hubungan mereka di tengah-tengah masyarakat (Johanes Waldes Hasugian, 2019) dan diharapkan juga kepada pemimpin Kristen untuk memahami konsep bukan hanya di dalam gereja tetapi dalam masyarakat (Tari et al., 2019). Walaupun ada hal-hal yang relevan dan prioritas tetapi diabaikan, dan ada juga hal-hal yang terkait erat tetapi dilupakan dalam kehidupan keluarga dan pelayanan gereja. Maka para guru tetap memiliki pemikiran yang mengacu bahwa Pendidikan Agama Kristen dalam konteks pelayanan keluarga dan 
gereja saat ini adalah hal yang penting (Kurniadi, 2015), dilakukan dan dijalankan senagai bagian dari peran dan tugas serta tanggung jawab sebagai bagian mencerdaskan spiritiual kerohanian Kristen dan karakter yang berkenan di hadapan Tuhan dengan memohon pada pimpinan dan pertolongan Roh Kudus. Karena pengenalan dan pengalaman akan Roh Kudus ini sangat penting untuk membangun kehidupan rohani murid-muird pendidikan agama Kristen untuk berkembang dan berbuah banyak, karena dikuasai dan ditumbuhkan serta disuburkan oleh Roh Bapa dan Anak yang bekerja dalam batin mereka.(Enklaar \& Homrighausen, 2011) meskipun guru, gereja dan keluarga menghadapi perubahan sosial,namun guru, gereja dan keluarga dalam mengarahkan dan pendidikan agama Kristen berperan dengan meresponi perubahan sosial secara Kristiani, lewat memohon hikmat Allah serta belajar dari Yesus yang memberikan suatu misi kepada umat-Nya agar mengasihi dan bersaksi serta melayani seperti teladan-Nya kepada murid-murid-Nya (Sagala, 2017). Sebab sejatinya proses belajar mengajar yang efektif membutuhkan kehadiran dan pekerjaan Roh Kudus yang kontinu (Pazmino, 2016, p. 47). Untuk membawa tugas pendidikan dalam menolong orang untuk mengembangkan dan mengambil bagian dalam masyarakat (Seymour, 2016, p. 56).

\section{REKOMENDASI PENGEMBANGAN PENELITIAN}

Penulis berharap hasil penelitian ini dapat bermanfaat bagi gereja, lembaga pendidikan dan terlebih kepada keluarga. Kiranya saran atau kritik dapat diberikan kepada penulis oleh semua pembaca agar dikesempatan selanjutnya penulis dapat lebih lagi dalam mengembangkan kemampuan yang telah diberikan oleh Tuhan. Penelitian ini masih dapat dikembangkan dengan melihat relevansi penelitian ini, dengan fakta-fakta di tahun-tahun selanjutnya, oleh orang-orang yang mau menguji atau mengembangkannya. Kemudian, penulis juga berharap kiranya penelitian ini dapat menjadi referensi dari penulis-penulis berikutnya yang sedang menulis tentang topik-topik seputar pembahasan yang ada pada artikel ini.

\section{KESIMPULAN}

Dengan demikian dapat ditarik kesimpulan bahwa untuk membawa generasi takut akan Tuhan dan ada dalam pertumbuhan iman, dan dalam nilai karakter yang baik, mengalami kasih dan pengenalan akan Tuhan secara pribadi pada diri anak didik adalah hal yang harus dilakukan oleh semua pihak baik gereja, sekolah, orang tua atau keluarga, sebab 
kebutuhan akan manusia yang memiliki sumber saya manusia yang berkarakter baik sangat langka saat ini. Dan guru yang dekat dengan murid diharuskan menjadi teladan dalam meningkatkan kerohanian dan karakter peserta didik yang dapat membawa keluarga, gereja dan bangsa menjadi lebih baik. Sebab arah dan tujuan dan pendidikan agama Kristen sudah jelas yaitu pendidikan yang berpusat kepada Allah. Penulis ingin menyampaikan tujuan tersebut didalam penelitian kajian literature yang diharapkan para guru PAK dalam perannya dapat membawa transformasi bagi peserta didik dalam kerohanian dan karakter yang berkenan dihadapan Tuhan dan sesama sehingga nama Tuhan dipermuliakan.

Peran Guru PAK sebagai teladan dalam meningkatkan kerohanian dan karakter peserta didik. Adalah kajian yang dapat memberikan pemahaman bagi guru pendidikan agama Kristen tentangnya Sumber daya manusia yang dimaksimalkan sebagai dasar membangun masa depan peserta didik dalam menghadapi tantangan dan persoalan hidup, sehingga mereka dapat keluar mengatasi persoalan tersebut. Dengan sebagai teladan maka guru dalam penelitian ini diminta yang pertama memiliki tanggung jawab dalam mengerjakan tugas, Peran dan tanggung jawab guru pendidikan Agama Kristen. Lalu guru harus menyadari bahwa guru Pendidikan Agama Kristen sebagai pemimpin keteladanan. Dan selanjutnya Guru bekerja sama dengan gereja dan keluarga membawa dalam peningkatan kerohanian dan karakter. Dan yang terakhir Guru harus dipimpin Roh Kudus.

\section{BIODATA}

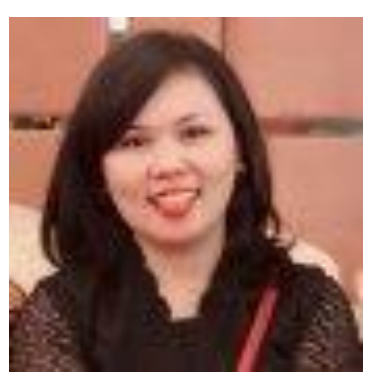

Reni Triposa adalah penulis dari Sekolah Tinggi Teologi Sangkakala. Dia banyak menulis tentang teologi dan pendidikan Kristen. Pada tulisannya ia seringkali mengintegrasikan karakter dan fenomenafenomena yang terjadi dengan pandangan teologis Alkitab sebagai jawaban atas segala sesuatu yang terjadi.

\section{Reni Triposa}

Surel: renitriposa@sttsangkakala.ac.id 


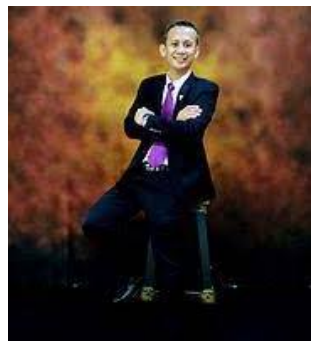

Yonatan Alex Arifianto adalah dosen Sekolah Tinggi Teologi Sangkakala. Dia melanjutkan studi doktoral di Sekolah Tinggi Baptis Indonesia. Dia menekuni bidang teologi, pendidikan Kristen dan misiologi, hal tersebut terlihat pada usahanya selama ini. Dia juga sangat senang berkolaborasi dengan dosen-dosen yang berada di luar lembaga yang menaunginya.

\section{Yonatan Alex Arifianto}

Surel:arifiantoalex@stbi.ac.id

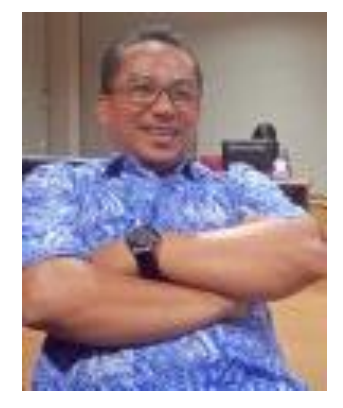

Yudi Hendrilia adalah dosen tetap di Sekolah Tinggi Teologi Kanaan Nusantara. Dia banyak menulis tentang pendidikan Kristen. Tulisan-tulisan yang dibuatnya lebih menekankan solusi Alkitab terhadap situasi yang terjadi pada masa kini. Melalui tulisan yang ia buat diharapkan dapat menjadi jawaban yang dicari oleh banyak orang di era kemajuan teknologi seperti ini.

\section{Yudi Hendrilia}

Surel: yudihendrilia@gmail.com

\section{REFERENSI}

Andrianti, S. (2012). Pendidikan Kristen: Keseimbangan antara Intelektual dan Spiritualitas. Jurnal Antusias, 1-32.

Andriati, S. (1948). PEMAHAMAN TENTANG KARUNIA ROH KUDUS

\section{DALAMPEMBERDAYAAN KUALITAS GURU PENDIDIKAN AGAMA KRISTEN.} In Jurnal Antusias.

Arifianto, Y. A., \& sumiwi Rachmani, A. (2020). Peran Roh Kudus dalam Menuntun Orang Percaya kepada Seluruh Kebenaran Berdasarkan Yohanes 16 : 13. Jurnal Diegesis, 3(1), $1-12$.

Azzahra, A., \& Haq, A. L. A. (2019). Intensi Pelaku Perundungan (Bullying) : Studi

Fenomenologi Pada Pelaku Perundungan di Sekolah. Psycho Idea.

https://doi.org/10.30595/psychoidea.v17i1.3849

Baskoro, P. K. (2020). Landasan Psikologis Pendidikan Kristen dan Relevansinya dalam Pendidikan Kristen Masa Kini. Jurnal Pendidikan Agama Kristen (JUPAK), 1(1), 47- 
67. https://doi.org/10.52489/jupak.v1i1.6

Berkhof, L., \& Til, C. Van. (2012). Dasar Pendidikan Kristen: Dasar Pendidikan Kristen:

Ceramah-ceramah kepada Guru-guru Kristen. Momentum.

Budiyana, H. (2018). Roh Kudus Dalam Proses Pembelajaran Pendidikankristen

Mewujudkan Pengajaran Kristen Yang Mengandung Nilai Kekal. Jurnal Teologi Berita

Hidup, 1(1), 57-77. https://doi.org/10.38189/jtbh.v1i1.5

Budiyana, H. (2020). Peran Psikologi dalam Pendidikan Kristen di Sekolah Kristen. Jurnal

Pendidikan Agama Kristen (JUPAK), 1(1), 68-78. https://doi.org/10.52489/jupak.v1i1.9

Chusna, P. A. (2017). Pengaruh Media Gadget Pada Perkembangan Karakter Anak.

Dinamika Penelitian: Media Komunikasi Sosial Keagamaan, 17(2), 315-330.

https://doi.org/10.21274/dinamika/2017.17.2.315-330

Dan, S., \& Afriyeni, N. (2017). Perilaku Perundungan Maya (Cyberbullying) Pada Remaja

Awal. Jurnal Psikologi Insight (C) Psikologi Universitas Pendidikan Indonesia, 1(1), 25-

41. https://doi.org/10.5281/zenodo.582669

Darmawan, I. P. A. (2014). Pendidikan Kristen Era Postmodern. Jurnal Simpson: Jurnal

Teologi Dan Pendidikan Agama Kristen, Setiawan 2007, 31-40.

Denney, A. S., \& Tewksbury, R. (2013). How to Write a Literature Review. Journal of

Criminal Justice Education, 24(2), 218-234.

https://doi.org/10.1080/10511253.2012.730617

Dewanti, T., Widada, W., \& Triyono, T. (2016). Hubungan Antara Keterampilan Sosial Dan

Penggunaan Gadget Smartphone Terhadap Prestasi Belajar Siswa Sma Negeri 9 Malang.

Jurnal Kajian Bimbingan Dan Konseling, 1(3), 126-131.

https://doi.org/10.17977/um001v1i32016p126

Eli Tanya. (2006). Gereja daan Pendidikan Agama Kristen. sekolah tinggi teologi cipanas.

Eliasaputra, M. P., Novalina, M., \& Siahaan, R. J. (2020). Tantangan Pendidikan Agama

Kristen Di Era Revolusi Industri 4.0 Dan Pasca Kebenaran. BONAFIDE: Jurnal Teologi

Dan Pendidikan Kristen, 1(1), 1-22. https://doi.org/10.46558/bonafide.v1i1.7

Enklaar, I. H., \& Homrighausen, E. G. (2011). Pendidikan Agama Kristen. Jakarta: BPK Gunung Mulia.

Ermindyawati, L. (2019). Peranan Guru Pendidikan Agama Kristen Terhadap Perilaku

Siswa-Siswi Di SD Negeri 01 Ujung Watu Jepara. FIDEI: Jurnal Teologi Sistematika

Dan Praktika, 2(1), 40-61. https://doi.org/10.34081/fidei.v2i1.27

GP, H. (2012). Pendidikan Agama Kristen dalam Alkitab dan dunia Pendidikan Masa kini. 
Penerbit Andi.

Hastuti, R. (2013). Pendidikan Agama Kristen Dalam Keluarga Sebagai Pusat Bermisi. Jurnal Antusias, 2(4), 23-68.

Hendrick, howard G. (2011). Mengajar Untuk Mengubah Hidup. Yayasan Gloria.

Hubungan Peran Keluarga Dalam Menghindari Dampak Negatif Penggunaan Gadget Pada

Anak Dengan Perilaku Anak Dalam Penggunaan Gadget Di Desa Kiawa 2 Barat

Kecamatan Kawangkoan Utara. (2018). Jurnal Keperawatan, 6(2).

Hutabarat, O. R. (2019). Mendidik Anak Berkarakter Kristen Mengatasi Kekerasan. Voice of

Wesley: Jurnal Ilmiah Musik Dan Agama, 1(2). https://doi.org/10.36972/jvow.v1i2.12

Hutagalung, P. (2020). Pemuridan Sebagai Mandat Misi Menurut Matius 28:18-20.

Pengarah: Jurnal Teologi Kristen, 2(1), 64-76.

https://doi.org/10.36270/pengarah.v2i1.22

Intarti, E. R. (2016). Peran guru pendidikan agama Kristen sebagai motivator. Regula Fidei, 1(2), 28-40. https://doi.org/10.33541/regula fidei.v1i2.626

Johanes Waldes Hasugian. (2019). Kurikulum Pendidikan Kristen bagi Orang Dewasa di Gereja. KURIOS: Jurnal Teologi Dan Pendidikan Agama Kristen.

https://doi.org/10.30995/kur.v5i1.96

Kurniadi, T. (2015). Tinjauan Teologis Paedagogis Korelasi Pendidikan Agama Kristen (Pak)

Gereja Dan Keluarga Dan Relevansinya Bagi Pelayanan Gereja Masa Kini. Manna Rafflesia, 2(2), 69-87. https://doi.org/10.38091/man_raf.v2i2.57

Lumban Gaol, N. T., \& Nababan, A. (2019). Kepemimpinan Guru Pendidikan Agama

Kristen. Kelola: Jurnal Manajemen Pendidikan.

https://doi.org/10.24246/j.jk.2019.v6.i1.p89-96

Maulida, O. H. (2013). Menelisik Pengaruh Penggunaan Aplikasi Gadget terhadap

Perkembangan Psikologis Anak Usia Dini. Universitas Negeri Semarang.

Nadeak, E. H., \& Hidayat, D. (2017). Karakteristik Pendidikan yang Menebus di Suatu

Sekolah Kristen [The Characteristics of Redemptive Education In a Christian School].

Polyglot: Jurnal Ilmiah. https://doi.org/10.19166/pji.v13i2.439

Niyoko. (2017). Pendidikan Agama Kristen Untuk perguruan Tinggi. Yayasan Taman Pustaka Kristen Indonesia.

Nuh, S., Darmawan, I. P. A., \& Sujoko, E. (2019). Implementasi Pak Konteks Gereja Di Gkii Tandang, Semarang. Pengarah: Jurnal Teologi Kristen, 1(1), 59-70.

https://doi.org/10.36270/pengarah.v1i1.7 
Nuhamara, D. (2018). Pengutamaan Dimensi Karakter Dalam Pendidikan Agama Kristen. Jurnal Jaffray, 16(1), 93. https://doi.org/10.25278/jj71.v16i1.278

Pazmino, R. W. (2016). Fondasi pendidikan Kristen. BPK Gunung Mulia.

Rantung, D. A. (2017). Pendidikan Agama Kristen Dalam Kehidupan Masyarakat Majemuk. Shanan Jurnal Pendidikan Agama Kristen, 1(2), 177.

Rastati, R. (2016). Bentuk Perundungan Siber Di Media Sosial Dan Pencegahannya Bagi Korban Dan Pelaku. Jurnal Sosioteknologi, 15(2), 169-186.

https://doi.org/10.5614/sostek.itbj.2016.15.02.1

Sagala, L. D. (2017). Peran Pendidikan Agama Kristen dalam Menghadapi Perubahan Sosial. Jurnal Simpson: Jurnal Teologi Dan Pendidikan Agama Kristen, 1(1), 48.

Sahartian, S. (2018). Pemahaman Guru Pendidikan Agama Kristen Tentang II Timotius 3:10 Terhadap Peningkatan Kecerdasan Spiritual Anak Didik. FIDEI: Jurnal Teologi Sistematika Dan Praktika. https://doi.org/10.34081/fidei.v1i2.15

Santoso, M. P. (2005). Karakteristik Pendidikan Kristen. Veritas : Jurnal Teologi Dan Pelayanan. https://doi.org/10.36421/veritas.v6i2.153

Saptono Yohanes Joko. (2016). Motivasi dan keberhasilan belajar siswa. Jurnal Pendidikan Agama Kristen, I(1), 189-212.

Saragih, E. S. (2019). Fungsi Gereja Sebagai Entrepreneurship Sosial dalam Masyarakat Majemuk. Kurios: Jurnal Teologi Dan Pendidikan Agama Kristen.

Setianingsih, Amila Wahyuni, A., \& Firiana Noor, K. (2018). Dampak Penggunaan Gadget Pada Anak Usia Prasekolah. Gaster.

Seymour, J. (2016). Memetakan Pendidikan Kristen. BPK Gunung Mulia.

Siburian, T. (2019). Pengembangan Model Pembelajaran Pendidikan Agama Kristen Melalui Pendekatan Kontekstual (Contextual Teaching and Learning/CTL) pada Siswa Kelas IV Dan .... PROVEDENSI: Jurnal Pendidikan Dan Teologi.

Sidjabat, B.S. (2017). Mengajar secara Profesional. kalam hidup.

Sidjabat, Binsen S. (2020). Meretas Polarisasi Pendidikan Kristiani. Indonesian Journal of Theology, 7(1), 7-24. https://doi.org/10.46567/ijt.v7i1.2

Simanjuntak, R. (2016). Dampak Keteladanan Yesus sebagai Guru Agung bagi Guru Pendidikan Agama Kristen Masa Kini. Sanctum Domine: Jurnal Teologi, 4(2), 29-40. https://doi.org/10.46495/sdjt.v4i2.24

Simorangkir, N., \& STAKN Tarutung, D. (2013). Peran Guru Pendidikan Agama Kristen Dalam Pembentukan Karakter Anak Didik Melalui Proses Pembelajaran. Jurnal 


\section{Reni Triposa, Yonatan Alex Arifianto, Yudi Hendrilia}

Saintech.

Sutoyo, D. (2016). Allah Memanggil Umat-Nya Untuk Menjadi Gereja Yang Tekun Berdoa Menurut Kisah Para Rasul 4: 23 - 31. DUNAMIS: Jurnal Penelitian Teologi Dan Pendidikan Kristiani, 1(1), 52. https://doi.org/10.30648/dun.v1i1.101

Tari, E., Mosooli, E. A., \& Tulaka, E. E. (2019). Kepemimpinan Kristen Berdasarkan 1 Timotius 3:1-7. Jurnal Teruna Bhakti, 2(1), 15-21.

Telaumbanua, A. (2019). Peran Gembala Sidang Sebagai Pendidik Dalam Pertumbuhan Rohani Jemaat. FIDEI: Jurnal Teologi Sistematika Dan Praktika, 2(2), 362-387. https://doi.org/10.34081/fidei.v2i2.45

Umrati, \& Wijaya, H. (2020). Analisis Data Kualitatif Teori Konsep dalam Penelitian Pendidikan. Sekolah Tinggi Theologia Jaffray.

Utomo, B. S. (2017). (R)Evolusi Guru Pendidikan Agama Kristen dalam Mentransformasi Kehidupan Siswa. DUNAMIS: Jurnal Penelitian Teologi Dan Pendidikan Kristiani, 1(2), 102. https://doi.org/10.30648/dun.v1i2.111

Wadi, E. N., \& Selfina, E. (2016). Peran Orang Tua Sebagai Keluarga Cyber Smart Dalam Mengajarkan Pendidikan Kristen Pada Remaja GKII Ebenhaezer Sentani Jayapura Papua. Jurnal Jaffray. https://doi.org/10.25278/jj71.v14i1.190

Widianing, O. J. (2018). Pendidikan Kristen di Sekolah: Sebuah Tugas Ilahi Dalam Memuridkan Jiwa. Jurnal Teologi Berita Hidup, 1(1).

https://doi.org/10.38189/jtbh.v1i1.6 